\title{
Property Market Efficiency: Developed or Vacant Property
}

\author{
Azima Abdul Manaf ${ }^{1}$, A. C. Er ${ }^{1}$, Ismail O. ${ }^{1}$, N. Lyndon ${ }^{1}$, S. Sivapalan ${ }^{1}$, Mohd Yusof Hussain ${ }^{1}$, Suhana Saad ${ }^{1}$, R. \\ Zaimah $^{1}$, M. S. Sarmila ${ }^{1} \&$ M. J. Fuad ${ }^{1}$ \\ ${ }^{1}$ School of Social, Development and Environmental Studies, Faculty of Social Sciences and Humanities, \\ Universiti Kebangsaan Malaysia, Bangi, Malaysia \\ Correspondence: Azima Abdul Manaf, School of Social, Development and Environmental Studies, Faculty of \\ Social Sciences and Humanities, Universiti Kebangsaan Malaysia, 43600 Bangi, Malaysia. Tel: 60-19-286-4332. \\ E-mail: azima@ukm.my
}

\author{
Received: July 22, 2013 Accepted: September 1, 2013 Online Published: October 11, 2013 \\ doi:10.5539/ass.v9n14p63 \\ URL: http://dx.doi.org/10.5539/ass.v9n14p63
}

\begin{abstract}
Property market efficiency in terms of adequate supply of land for proper use will have a strong impact on the value of urban real estate. Land supply plays an important role in providing space for housing which also includes meeting the demands of the commercial and industrial sectors. Hence, the distribution of urban land for development will affect the structural development of a city. Meanwhile, the existence of vacant urban land can lead to an unbalanced real estate development. This paper therefore aims to examine property efficiency relationship between real estate ability and the development process. Literature review from previous studies suggests that it is possible to examine property market efficiency. The term 'efficiency' has been viewed from different perspectives of theories or approaches by various researchers. Interestingly, many researchers have tried to examine property efficiency issues from the conventional approach until the emergence of the need to provide an alternative economic institutional approach. Institutionalisms consider rules, policy and organisations and the way these may govern agents' social relations and their attitudes in the society. It means the major role of institutions in a society is to reduce uncertainty by establishing a stable structure to human interaction.
\end{abstract}

Keywords: property market, efficiency, land supply, vacant property and development process

\section{Introduction}

Land has been identified as a key determinant of economic and social development. Generally, land supply plays an important role in providing housing which includes a variety of options to meet the needs of commercial and industrial sectors. Hence, the distribution of urban land for development will affect the structural development of a city. The existence of vacant urban land can lead to an unbalanced real estate development. As such, the government has to consider the adequacy of land supply which is a key input affecting the interest and benefit of urban residents. Therefore, it is not surprising if land supply strategy becomes an important part of the social and economic development strategy. This is because land supply strategy tends to provide guidance to property owners, potential owners, property investors, organizations, and the industrial sector. In a concrete sense, land supply strategy can be viewed as a long term solution to land use and property issue in urban areas.

The strategy of property development is a key tool in formulating government policy. As such, land supply strategy of property development may have the following benefits: (1) helping to enhance the social and economic development; (2) achieving optimum benefits for community purposes; (3) providing various choices of land and housing development opportunities; (4) enabling the development of land by private sector to encourage greater competition; and (5) ensuring future investments have a level of certainty in terms of availability of land supply and its pricing.

This paper aims to examine property efficiency in terms of the availability of real estate property land in the course of the development process. This is because the relationship between the availability of land and the development process has a major impact on the issues of property efficiency which is considered to be very complex.

\section{Land Supply Issues and Efficiency}

The phenomenon of the existence of vacant urban land can lead to an unbalanced real estate development. Besides that, vacant land areas can have negative implications for urban economic development strategy such as 
in terms of efficiency and responsiveness (Michael \& Bowman, 2000).

Burrows (1978) interprets a city with vacant land as unused land which is usually overgrown with wild vegetation or covered with rocky surface or with abandoned buildings. In addition, Michael and Bowman (2000) explained that abandoned or vacant urban land involves both the public or private property that is not in use or abandoned without infrastructure or access to infrastructure, where the land has been left undeveloped. This particular classification focuses on land parcels which are characterised by particular types of activity (e.g under use, non use, temporary use) in combination with particular types of physical structure (e.g complete building, part-demolished building, cleared sites, tips). There are several "forms" of vacancy have been identified. A fairly full classification would distinguish between:

1) land and building underuse

2) building vacancy

3) dereliction of building and other operation e.g tips, disused railway sidings

4) vacant land (building demolished and removed)

5) temporarily used but otherwise vacant land

6) Other categories of land and building underuse (prior to full use and occupancy) e. g grassing over of previously unused land, some public open space

Studies on 'vacant urban land' mostly focus on factors that led to their existence in cities, taking into account the concept of urban vacant land introduced by Burrows (1978) and Michael and Bowman (2000). Studies conducted by Evans (1985), Gore and Nicholson (1985), Burrow (1978), MacGregor (1985), Chisholm and Kivell (1987), as well as Cameron et al. (1988) have focused on the main causes of vacant urban land which are often attributed to lifestyles, technology and demographic factors. Similarly, studies by local scholars such as Abd Lateh @ Latiff (2005), Tan Hui Lian (2001), Ishak (1991) and Wan Abd. Aziz (1986) have examined the causes of urban vacant land in Malaysia in the context of economic, political and social factors.

Greenstein and Sungu-Eryilmaz (2004) explicate that there are several factors that can be attributed to the rise of 'vacant land' in urban areas, namely moving out of business, residential areas located in the downtown area, and discrimination in investment opportunities. In addition, studies on urban vacant land involving large blocks of land holdings were found to have contributed to the understanding of urban wasteland or vacant land as well. A study by Ismail Omar (1999) on the Malay Agricultural Settlement (MAS) scheme in Kampong Baru, Kuala Lumpur found that the MAS land was designated as an agricultural reserve land, but since it was not developed, it ultimately became a 'vacant land' in the urban area. Most of these studies on urban vacant land have concentrated on the causes of urban vacant land. The urban vacant land concept denotes the idea of urban wasteland where the area has been abandoned and left undeveloped and generally have dilapidated buildings on it. As an example, Greenstein and Sungu-Eryilmaz (2004) have classified vacant land as an urban wasteland; however, they did not emphasize the function of urban vacant land. Several gaps that exist in past studies on vacant land have failed to provide adequate attention to issues of identification, classification and functions of vacant land. These gaps have led to the persistence of this vacant land issue. City administrators need to take into account these gaps in order to facilitate economic development that could ensure adequate land and property development process.

Documented source from DBKL (2000) asserts that 'vacant land' in the urban areas has not only led to imbalance in urban development, but has also caused ineffective use of land such as slum areas and illegal parking areas. As a consequence, loss of council tax collection has reduced the revenue for local authorities, thus making redevelopment process difficult because of the increasing cost. Although there was intervention by the authority in preparing the planning zone, they were not able to solve the problem of urban 'vacant land' in the city.

The implication of the emergence of vacant land is that it has resulted in losses in collection of land tax for the state government, in which in 2000 it was reported to be at about RM15 million a year, including some 5.756 hectares of urban land which were not developed, and this came to about 23 percent of the overall land use in Kuala Lumpur (Mutazar, 2000). In fact, by law and by institutional protection, vacant land should not be a phenomenon because the law under Section 115, 116 and 117 of the National Land Code 1965, explicitly states that the land that has been left vacant for a period of time (i.e. 2 years for land and buildings, and 3 years for agricultural and industrial use) will be liable to seizure as provided for under Section 129 (4) (c) in the National Land Code 1965 (National Land Code 1965). Section 129 (4) (c) provides that the Administrator could take the temporary rights of the land as directed by the State Authority or in the absence of such direction, make an order to declare the land confiscated by the State Authority. 
Having considered all these, the question raised is how can land in urban areas be used more optimally. In a competitive environment, vacant land use in the urban area is better described as urban wasteland. As such, this situation would threaten the efficiency of land and property development process in the city space.

\section{Literature Review}

The relationship between planning policy and land use is a complex one as it is difficult to ensure demand is fulfilled by supply since the changes in market are drastic and uncertain. A study by Jackson et al. (1994) in Fenland, South Cambridgeshire and North Hertfordshire found that all three regions face different constraints in terms of land development process, and the three regions adopt different development plans. In terms of output, contraint in North Hentfordshire appeared to "iron out" some of the boom-slump variations in completions and outstanding permissions observed elsewhere. South Cambridgeshire reacted more to changing market conditions. But it was in Fenland, the least contrained area, that dramatic changes could be seen, with both output and prices rising rapidly in the boom only to be followed by equally rapid decline. The researches conclude that release of housing land in one area cannot fully substitute for contraint in another. Neither can the planning system as a whole absorb sudden changes in demand.

Additionally, Krabben et al. (2007) in their work discussed the understanding of spatial efficiency of industrial land where the authors explained the concept of space efficiency which has a close relationship with the productivity of space. According to Andrea Sarzyshi and Alice, L (2010) the term of spatial efficiency means the use of land such that the most output possible is produced. Therefore productivity efficiency refers to an output that is produced from a total amount of land (value added per square foot). In comparison, space efficiency generally involves numbers, where it involves the effectiveness of the production process. For example, an industry or firm leads the production of space efficiency output based on per acre land use. Thus, firms will use more land to produce more output. An empirical case in the Netherlands' using regression analysis of land productivity by taking into account several variables such as rates of urbanization, the ratio of supply and increased demand for industrial information such as the ratio of manufacturing workers and the ratio of employment to transport. The authors suggested that the strategy of industrial development should focus on improving space efficiency and productivity space for the return of the land area by using the variable industry sector, supply of land and regional economic growth. Hence, they also suggested the need to assess the property right theory in order to examine the efficiency of industrial land in a more systematic manner.

Besides space efficiency, the notion of market efficiency was emphasized by Akee (2006). In his article about the role of transaction costs, he postulates the outcome of the efficiency of markets. By using the Coase Theorem, researchers tried to identify the optimal efficiency of the market return, where they found that the market and property rights alone cannot ensure optimal market results. Accordingly, the theorem attempts to identify the barriers to the market. Among the data used were a time series data analysis and a cross tabulation of two variables (i.e. value with land tax) to determine the effect of reducing the significance of transaction costs on efficiency that yield on the land market.

Jun Iritani and Yeoun Tae Lee (2007) used the Coase Theorem in their research and divided it into two sub-theorems. It looked at the allocation of resource efficiency that can be achieved from the supply land when a variety of agents are involved. Both involved the allocation of resources that not only depended on the state. The early writings by Coase (1960) was based on bargaining which involves internal and external social costs. However, it does not necessarily need to be based on market forces. Therefore, market efficiency cannot be obtained if the transaction costs become too high or there is no complete information.

Turnbull (2006) used the model of rate of return regulation model for land efficiency and its implications on land use. His paper described the direct result of giving power to a private firm in decision-making relating to land development. The research attempted to see with greater detail the relationship of the regulation on firms which utilize land in the market that can eventually lead to land efficiency. Regulation theory suggests that by giving appropriate incentives, more capital will be generated leading to positive effect toward land efficiency. However, they explained that the results showed that firms following the Pareto guidelines will provide an institutional efficiency orientation for the government in regulating the use of the land for development purposes. An example is privatization as an institutional efficiency mechanism in the past. Gregory Clark (1998) examined the evolution and growth of agricultural land in Europe since 600 years ago in which the privatization of this sector has resulted in huge profits obtained since the last 18 decades (1830). However, as a consequence of this historical process, land ownership has created 15 percent of wasteland that can be used as potential income for several generations. Therefore, Gregory Clark (1998) provided a solution by suggesting that changes in relative prices will lead to marginal gains to those parties involved and thus resulting greater land efficiency. 
Besides market efficiency, the idea of institutional efficiency is also explored in detail. Keogh and D'Arcy (1999) highlighted the debate on the efficiency of property market by using the institutional approach. They considered efficiency of the property market as having specific criterion related to property owned by them (market) which also includes the development process. They argue that the institutional dimension can bring about changes toward the existing notions of land efficiency. As such, the institutional approach views the development process of the property market as a key entity within the efficiency framework in the property market. They also incorporated the time dimension as a key element in the process of social and economic changes whilst examining the property market's capabilities.

In examining the institutional approach, one of the main institutions that warrants attention is the economic institutions. Arvanitidis (2006) raised the issue of land efficiency of the market from the perspective of economic institutions. This means that the institutional economics analysis focuses on the important performances of actors. He believes that most of the efficiency concepts which have been used in the property market are conventional views, such as productive efficiency, space efficiency and the market efficiency hypothesis. These conventional approaches refer to the contemporary ideal benchmark without taking into account the nature and dynamics of the development process that occurs in the property market. In his study, he suggested a review of the property efficiency for land valuation in the market which involves to find a vision of sustainable economic development. In order to ensure the idea of the property market efficiency, he suggested two theoretical concepts/notions. The first is institutional uncertainty and the second, the notion of institutional diversity. Institutional uncertainty involves the impact/effect of existing institutional structure on the interpretation/understanding of urban quality and the extent to which it is effective in enhancing the socioeconomic conditions of the urban communities and ultimately providing better economic opportunities/environment. Meanwhile, the diversity of institutions assesses the operational details of such diverse institutions in the property market institutions, organizations and products that are available. As such, there is the need to include micro and macro level analysis involving time series data and to capture the dynamics of these economic institutions.

From the previous studies, it can be seen that various different authors view the term efficiency in property market from different perspectives of theories or approaches and in different contexts. Interestingly, many authors examined the issue of property efficiency in the context of conventional notion of efficiency until the emergence of the economics institutional approach. However, the study found that in order to examine the efficiency of the property market, researchers need to use time series analysis to capture the dynamics of the real estate sector so as to be able to identify the market potential in terms of the economic and social changes. It is apparent from the reviews by Keogh and D'Arcy (1999) and Arvanitidis (2006) that focused on the theorization of the economic and social changes that the institutional economics analysis framework provides an alternative tool to explain the nature of land development process.

\section{Development Process - Considering Constraints on Land Supply for Development}

Land development is a complex process in the built environment. This complexity is mainly due to spatial and temporal variation between one development project and another (Ratcliffe \& Stubbs, 1996; van der Krabben, 1995). Although various theoretical approaches attempt to consider fully the whole range of issue in the land process, they contain both strengths and weaknesses in representing the complex nature of the built environment production. In general, various theoretical approaches consider the actor and the wider external forces which affect their decisions in the land development process (Gore \& Nicholson, 1991; Healey \& Barret, 1990; Healey, 1992).

Neoclassical economics emphasizes the importance of the price mechanism and resource allocation but tends to neglect the effect of economic changes and market instability in the land process (Healey, 1991). Moreover, with the general view and assumption on economic rationality, the neoclassical approaches fail to address the co-ordination needed in dealing with human social relation (Van der Krabben, 1995). According to Hodgson (1988), by relying on the device of rational economic man, neoclassical theories tend to ignore the entire manner in which the human agent behaves, thus neglecting the dynamic and evolutionary nature of the market processes. With reference to constraints on the land supply for development, the models consider selective distortions which range from individual decisions to government intervention.

The empiricist approach focuses on the limited scope of events and agents' activities but the breakdown of events is too broad and fails to highlight adequately the sequential overlapping. Furthermore, it fails to explain the important role of key actors and their interests comprehensively (Healey, 1991). Nevertheless, the event-sequence models are able to show the occurrence of supply blockages in the development process which plays an important role in determining the feasibility of the development process. However, the empiricist 
approach is lacking in dynamic concepts and is inadequate in considering the driving forces of land development and the way these may affect the actors' decisions on land development.

The humanist approach considers the individual actor's behaviour as playing a vital role in restricting the supply of land development. A passive or active landowner may influence the development decisions, especially at the early stages of land development process. The behaviourist approach however, tends to over-emphasize the managers' role and neglect the consumer related roles (Monk et al., 1991).

Structural approaches concentrate on the broader social, economic and political forces including land policy, planning, funding, taxation and the essential provision of land development. This means that structural approaches emphasize more on the general setting of the broader driving forces rather than concentrate on the elements that constitute human activities (Backhouse, 1987). Structural approaches however, hardly offer ways to link events and actors' behaviour to broader social, economic and political processes, thus providing little insight into the role of landowning and capital accumulations. Since limited role is given to the whole range of development difficulties, these approaches are inadequate in addressing the complex nature of the development process, in particular the constraints on land supply development.

The structure and agency model introduces the linkage between rules, resources and ideas and roles, interests, strategies and actions of actors through land right labour, finance, information and expertise. Although Healey (1992) cited the importance of formalized and in formalised rules in the linkage between structure and agency, she did not elaborate explicitly on the ways in which these rules affect the land supply of land for development. Furthermore, Healey's (1992) model was weak in terms of the imperfect dichotomy between structure and agency (Ball, 1998) and the problems related to the definition of institutions (Hooper, 1992). As a result of these weaknesses, Healey's (1992) model is inadequate in explaining the constraints on land supply for development purposes.

Institutional analysis models consider various institutions affecting human interactions which are responsible for the direction of institutional change in the society. The institutional change underlies various rules, interactions and institutional constraints affecting the economic performance of human agents. This means that institutional economic models tend to explain the land development process extensively by having a much richer insight into the linkage between formal and informal rules or institutions through the exercise of agency relations by agents in the land process (North, 1996; van der Krabben, 1995). The formal and informal rules may lead to formal and informal constraints which govern the actors' decisions and the way they interact and hence restrict the supply of land for development. According to institutionalises, there are formal written rules and policies in the land development process, in particular planning and development regulations which restrict the supply of land for development purposes. On the other hand, there are informal unwritten rules such as custom, tradition, perspectives, values, and collective behaviour which may constrain the agents' decisions and affect their social interaction in the land development process.

\section{Conclusion}

The relationship between property market and efficiency can be examined in the context of land supply. Limited land supply, in particular for residential use, has been an acute problem when a land area in the city has been identified as having potential for development but was undeveloped, leading the land area to be considered as under-utilised and vacant. These vacant, under-utilised and undeveloped lands are subject to various land supply constraints. Past research has identified several indicators that can enhance land efficiency, namely a safe, attractive, and healthy environment that can at the same time offer educational opportunities, employment, entertainment and social attraction. Additionally, other indicators include physical ownership marketability, infrastructure, land use, financial deficit and pollution. All indicators were found to influence urban land efficiency in the context of providing housing to the city residents. Therefore, the institutional economics analysis is usually carried out in a descriptive way. The broad nature of formal and informal institutions, rules and constraints leads to a descriptive identification of formal and informal institutions, agency relations and agents' decisions which constrain the supply of land for development. In particular, the analytical tool of institutional economics analysis framework was utilised to investigate the existence, importance and implications of land supply constraints on the land development process.

\section{References}

Akee, R. (2006, November). Checkerboard and Coase: Transactions costs and efficiency in land market. Discussion Paper Series.

Amin, W. A. A. W. M. (1986). Pembangunan tanah terbiar di kawasan bandar: kajian kes di Tampoi, Johor. 
Unpublished Diploma, Diploma Perancangan Bandar dan Wilayah. Fakulti Alam Bina, Universiti Teknologi Malaysia, Skudai.

Arvanitidis, P. (2006). Property market purpose efficiency: an exploratory analysis from an institutional economics perspective. $46^{\text {th }}$ Congress of the Europen Regional Science Association (ERSA) Volos, 30 August -3 September 2006.

Backhouse, R. (1987). A History of modern economic analysis. Oxford:Basil Blackwell.

Ball, M. (1998). Institutions in British property research: a review. Urban Studies, 35(9), 1501-1517. http://dx.doi.org/10.1080/0042098984259

Burrows, J. (1978, January). Urban vacant land-a continuity crisis. The Planner.

Cameron, G. C., Monk, S., \& Perce, B. J. (1988). Vacant urban land: a literature review 1976- 1986. London: Department of Environment.

Chilsholm, \& Kivell. (1987). Recycling vacant land. London: Department Land Policy.

Evans, A. (1983). The determination of price of land. Urban Studies, 20, 119-129. http://dx.doi.org/10.1080/00420988320080271

Evans, A. (1985). Urban Economics. Oxford: Basil Blackwell.

Ghani, M. A. (2000). 1.6 juta hektar tidak boleh dimaju. Berita Harian.

Gore, A., \& Nicholson, D. J. (1985). The analysis of public land ownership and development. In S. Barret, \& P. Healey (Eds.), Land policy: problem and alternatives. Gower: Aldershot.

Gore, A., \& Nicholson, D. J. (1991). Model of the land development process: a critical review. Environment and Planning, 22, 705-730. http://dx.doi.org/10.1068/a230705

Greenstein, R., \& Sungu-Eryilmaz, Y. (2004). Recycling urban vacant land: neighbors reclaim neighborhood. London: Lincoln Institute Land Policy.

Hamnett, C. (2000). London's housing. London: Department of Geography, King's College London.

Healey, P. (1991). Models of the development process. Journal of Property Research, 8, 219-238. http://dx.doi.org/10.1080/09599919108724039

Healey, P. (1992). An institutional model of the development process. Journal of Property Research, 9, 33-44. http://dx.doi.org/10.1080/09599919208724049

Hodgson, G. M. (1998). The approach of institutional economics. Journal of Economic Literature, 36, 166-192.

Hooper, A. (1992). The construction of a theory: a comment. Journal of Property Research, 9, 45-48. http://dx.doi.org/10.1080/09599919208724050

Hussin, W. R. W. (2002). Siri pengajian dan pendidikan utusan: Impak pembangunan, kualiti hidup dan persekitaran. Kuala Lumpur: Utusan Publication \& Distributors Sdn Bhd.

Iritani, J., \& Lee, T. Y. (2007). A general equilibrium model with tradeable emission permit: efficiency and course property. Retrieved from http://www.econ.kobe-u.ac.jp/doc/seminar

Ismail, I. (1991). Kajian ke atas punca-punca tanah terbiar di kawasan bandar. kes kajian: kawasan perancangan pusat bandar Johor Bahru. Unpublished Thesis, Jabatan Penilaian dan Pengurusan Harta. Fakulti Kejuruteraan dan Sains Geoinfomasi, Universiti Teknologi Malaysia, Skudai.

Jackson, A., Monk, S., Royce, C., \& Dunn, J. (1994). Land supply and housing: a case study. Cambridge: Department of Land Economy, University of Cambridge.

Keogh, G., \& D’Arcy, E. (1999). Property market efficiency; an institutional economics perspective. London: Routledge.

Krabben, V. D., Erik, L., \& Amsterdam, V. (2007). Spatial efficiency of industrial land. $47^{\text {th }}$ Congress of the European Regional Science Association in Paris. August $29^{\text {th }}$ until September $2^{\text {nd }} 2007$.

Lian, T. H. (2001). Tanah terbiar di kawasan bandar Seremban : isu dan penyelesaian. Unpublished Masters Thesis, Ijazah Sarjana Pentadbiran dan Pembangunan Tanah. Universiti Teknologi Malaysia, Skudai.

Mac Gregor, B. D., Baum, A. E., Adam, C. D., Fleming, S. C., \& Peterson, J. (1985). Land availability for inner city development. Working Paper in Environmental Policy. No.8, Reading: Department of Land Management and Development, University Reading. 
Malaysia. (1965). Kanun Tanah Negara. Akta No 56/1965.

Malaysia. (1976). Akta Kerajaan Tempatan. Akta No 171.

Malaysia. (1976). Akta Perancangan Bandar dan Desa. Akta No 172.

Micheal, A. P., \& Bowman, A. O. (2000, December). Vacant land in cities: an urban resource. Survey Series.

Monk, S., Pearce, B., \& Whitehead, C. (1991). Planning, land supply and house price: a literature review. Cambridge: Department of Land Economy,University Cambridge.

North, D. C. (1996). Institution, institutional change and economic performance. Cambridge:University Press.

Omar, I. (1999). The Supply Constraints on Indigenous Land in Kuala Lumpur. Unpublished PhD Thesis in Land Economy:University of Aberdeen.

Osman, A. L. (2005). Faktor ekonomi sebagai punca tanah terbiar di dalam bandar: kajian kes pusat bandaraya Kuala Lumpur. Unpublished Masters Thesis Jabatan Penilaian dan Pengurusan Harta. Fakulti Kejuruteraan dan Sains Geoinfomasi, Universiti Teknologi Malaysia, Skudai.

Ratcliff, J., \& Stubbs, M. (1996). Urban planning and real estate development. London: Estate Gazette. http://dx.doi.org/10.4324/9780203428245

Sarzynski, A., \& Levy, A. (2010, August 16). Spatial effieciency and regional prosperity: a literature review and policy. Discussion: Working Paper.

Thornberg, C. (2007). Housing: supply demand imbalance. Conference on Real Estate and Development in the Northern Rockies. October 25 until 26, 2007.

Turnbull, G. K. (2006). Delegating eminent domain powers to private firms: efficiency and land use implications. Working paper No.06-01. August 2006.

Van der Krabben, E. (1995). Urban dynamic: a real estate perspective: An institutional analysis of production of build environment. Tilburg: Center for economic research, Tilburg University.

\section{Copyrights}

Copyright for this article is retained by the author(s), with first publication rights granted to the journal.

This is an open-access article distributed under the terms and conditions of the Creative Commons Attribution license (http://creativecommons.org/licenses/by/3.0/). 